\title{
Tourism and Economic Globalization: An Emerging Research Agenda ${ }^{1}$
}

\author{
Haiyan Song \\ The Hong Kong Polytechnic University, Hong Kong SAR, China \\ Gang Li \\ University of Surrey, United Kingdom \\ Zheng Cao \\ University of Surrey, United Kingdom
}

\begin{abstract}
Globalization characterizes the economic, social, political and cultural spheres of the modern world. Tourism has long been claimed as a crucial force shaping globalization, while in turn the developments of the tourism sector are under the influences of growing interdependence across the world. As globalization proceeds, destination countries have become more and more susceptible to local and global events. By linking the existing literature coherently, this study explores a number of themes on economic globalization in tourism. It attempts to identify the forces underpinning globalization and assess the implications on both the supply side and the demand side of the tourism sector. In view of a lack of quantitative evidence, future directions for empirical research have been suggested to investigate the interdependence of tourism demand, the convergence of tourism productivity and the impact of global events.
\end{abstract}

Keywords: Globalization, Economic Interdependence, Tourism Demand, Tourism Supply

\footnotetext{
${ }^{1}$ This paper should be cited as follows:

Song, H., Li, G., \& Cao, Z. (2017). Tourism and Economic Globalization: An Emerging Research Agenda. Journal of Travel Research, 0047287517734943.
} 


\section{Introduction}

Globalization is a buzzword of our time. Since its vague origins in the mid-twentieth century, the concept of globalization has found its vast and expanding presence in today's printed as well as virtual space (Held et al. 1999; Steger 2013). It has been widely used to describe a variety of economic, social, political and cultural changes that have shaped the world, especially over the past 50-odd years (Guttal 2007).

While it can be accorded multiple definitions from different perspectives, globalization is generally defined as a process (or a set of processes) that involves the compression of space and time and the intensification of economic, social, political and cultural interdependence on a global scale (Cohen 2012; Cornelissen 2005; Dicken 2011; Steger 2005). The process of globalization entails not only a high level geographical spread of economic activities, but also deep functional integrations of economic activities at local and regional levels (Dicken 2011). Globalization highlights the integration as well as the interdependence among economies (Fletcher and Westlake 2006).

From an economic perspective, globalization is manifested in international trade, international finance and mobility of people (Abel, Bernanke, and Croushore 2008; McGrew 2011; Stabler, Papatheodorou, and Sinclair 2010; Tribe 2011). All these three domains are deeply embedded within tourism activities. While tourism is seen as a major aspect in the process of globalization, globalization has given a significant impetus to the global growth of tourism (Azarya 2004; Cohen 2012; Cornelissen 2005). The spectrum of tourism economics literature would not be complete, had the tourism sector not been examined in the setting of globalization.

The current study reviews the literature on globalization of the tourism sector and its economic implications. Although globalization has appeared as the backdrop in many tourism studies, a comprehensive review is still lacking on how globalization develops in both the supply side and the demand side of the sector. By filling the void, this study aims to stimulate further discussions and shed light on future research directions.

The current study explores a range of themes surrounding the interdependent nature of the global tourism sector. It starts with identifying the influential forces behind globalization and noting the different views on the developments of globalization (Section 2). Then on the supply side, the study discusses the rationale behind corporate expansion and the integration of tourism businesses (Section 3); on the demand side, the study analyzes the mechanism of co-movements of tourism demand and, moreover, the interdependence between tourism markets (Section 4). The study then moves on to draw out the implications of a more and more globally integrated tourism sector from the perspective of business cycle synchronization and emphasizes the global impact of events (Section 5).

This study largely follows the narrative of economic geography and political economy. It elaborates on the topics qualitatively. The purpose of this study is to call for further empirical research, with the current study laying the theoretical foundation (Section 6). On the practical front, this study outlines a globalizing business environment where tourism businesses improve their performance through integration and at the same time face the challenges of global events. As such, further empirical research that quantifies various aspects of global business environment will be of particular importance. 


\section{Tourism and the Influential Forces behind Globalization}

Identifying the engines of globalization in the contemporary context can be difficult, as no coherent and systematic account exists (McGrew 2011). In the general literature, the influential forces behind globalization mainly fall into four deeply interrelated categories, namely the technics, economics, politics and culture (Dwyer et al. 2009; Fletcher and Westlake 2006; McGrew 2011; Mussa 2000). Given that tourism is an integrated part of the globalization process, it is not surprising to see that those forces appear in the tourism sector. As elaborated by Cohen (2012), tourism helped to create the modern global transportation system, through which remote destinations became easily and swiftly accessible, and also contributed to such establishments as airports, hotels and resorts; governments increasingly simplified formal procedures to facilitate the processing of growing numbers of tourists. Meanwhile, the globalization of tourism sector has also led to a fragmentation of tourism production system and the trans-nationalization of ownership structures, marketing arrangements, the outsourcing of services and the transmission of knowledge.

\subsection{Technics}

Technics is vital to any account of globalization. The developments of modern communication and transport technologies allow time and space to be compressed, so that a shrunken globe can be formed (McGrew 2011). Specifically, the advancements in communication technologies have helped to spread information and knowledge throughout the world at much lower costs, especially since the 1980s (Azarya 2004; McCann 2008). For the tourism sector, information and transport technologies are its lifelines, since it sells products on faith and its service providers are geographically dispersed (Dwyer et al. 2009; Fletcher and Westlake 2006). For example, computerized reservations systems (CRS) are believed to enhance small and mediumsized enterprises' (SMEs) profitability (Fletcher and Westlake 2006). Meanwhile, the improved transportation facilities and services make it more feasible and less costly for physical movements of not only goods (Fayed and Fletcher 2002) but also people across countries (Neumayer 2006). More profoundly, technological changes have facilitated the integration of the financial sector, where financial markets scattered around the world are now connected and transactions are carried out continuously on a real-time basis.

\subsection{Economics}

On the economic front, globalization is understood from the perspectives of market dynamics and imperatives of capitalism (McGrew 2011), which are widely discussed in economic geography. The logic of market dynamics considers globalization as a direct consequence of market competition. In theory, free trade allows countries to maximize their welfare based on their comparative advantages, whereas market forces and global competition enable goods and services to be produced efficiently at a minimum cost; meanwhile, key financial indicators such as interest rates become equalized so that the cost of financial leverage will be similar across countries (McGrew 2011; Redding 1999). Empirical evidence shows that free trade has resulted in income convergence at least among developed countries during the postwar period (Ben-David and Loewy 1998). The logic of capitalism follows the Marxist political economy argument that economic globalization is driven by profit seeking, which requires the continual search for new markets, cheaper labor and new sources of 
profitability and results in the expansion of corporations (McGrew 2011). For example, a hotel may pursue new markets outside the local area if it achieves the optimum share of a local or national market and is faced with overcapacity (Fletcher and Westlake 2006). For corporations, internationalization becomes a business strategy and is found to enhance firm values (Lee 2008).

It is worth pointing out that the expansion of economic activities is not without disruptions, for example, consumer movements for greater environmental sustainability. One of the counter-trends to globalization is the global economic crisis in recent years. To bring government finances under control, austerity programs were instituted, which were met with severe popular protests around the world as a growing distrust of and resentment against the leading financial institutions (Cohen 2012). In addition, the economic crisis also gave rise to protectionist pressure, such as the slowing pace of trade negotiations and the falling of support for free trade in some countries (Bussière et al. 2011). With regard to production patterns, the economic crisis caused a shift in the global value chain, where the EU as a whole lost some of its shares against extra-EU countries while only Greece and Spain improved their position within the EU's value chain (Ederer and Reschenhofer 2014).

\subsection{Politics}

The politics primarily concerns the ideological infrastructure of globalization. As noted by McGrew (2011), almost all accounts of contemporary globalization make reference to the rise and dominance of neoliberal ideology throughout the Organization for Economic Co-operation and Development (OECD) world, along with its associated policies of liberalization, deregulation and privatization (see also Mahon 2010; Scholte 2005). Since the 1970s, the dominant political trend among OECD countries has been towards the liberalization of national economies and the easing of restrictions on capital mobility (McGrew 2011). Governments have been instrumental in establishing the necessary national political conditions and policies. Promoted and advocated by a powerful configuration of domestic and transnational coalitions and lobbies, economic globalization is very much a political construction (McGrew 2011). Fayed and Fletcher (2002) place the emphasis on the liberalization in trade and investment, which is embodied by the establishment of the General Agreement on Trade and Tariffs (GATT), the General Agreement on Trade in Services (GATS) and policies promoting free current and capital account transactions by International Monetary Fund (IMF) (see also Scholte 2005; Simmons and Elkins 2004).

The liberalization in trade and investment boosts the worldwide tourism sector, especially on its supply side. For example, since the late 1990s, there has been an increasing level of transnational ownership and management of hotels, restaurants and travel agencies in many developing countries (Williams 2002). Moreover, the movement of tourists and labor is facilitated by the GATS via its rules and regulations, as it recognizes consumption abroad and presence of natural persons as modes of international service delivery (Williams 2002; Winters et al. 2003). In terms of migrant population, the world has seen its level triple from 82.5 million in 1970 to 243.7 million in 2015 (McGrew 2011; United Nations 2016).

The ongoing trend of liberalization and deregulation also faces resistance, especially with respect to the mobility of people. For example, visa restrictions are implemented by governments to deter some unwanted foreigners as well as the influx of 
immigrants (Cohen 2012; Neumayer 2006). There are security reasons behind visa restrictions. Indeed, security and political stability are fundamental preconditions for the prosperity of tourism in any destination (Dwyer et al. 2009). Meanwhile, it is inevitable that a country would experience detrimental impacts of visa restrictions on its trade, investment and tourism (Neumayer 2011; Song, Gartner, and Tasci 2012). In recent years, the resistance to free movement and to free trade has also been associated with the protectionist pressure, as globalization is perceived to contribute to widening wage inequalities in developed countries (Bussière et al. 2011).

\subsection{Culture}

Culture is also vital (Fayed and Fletcher 2002) to the process of globalization. The growth in population since World War II has created a demand for all kinds of economic goods, and the fact that population increases have not been evenly spread among countries implies trade opportunities (Fayed and Fletcher 2002). Cultural factors, including cultural exposure (e.g., the demonstration effect through media sources), have led to some degree of homogenization. This is sometimes termed as "McDonaldization", which according to George Ritzer is the process whereby the principles of the fast-food chain start to dominate more and more sectors of American society as well as the rest of the world (Pieterse 1996). The interpretation of the term would immediately imply the primacy of American culture; from films, music and modern art to casual clothing, fast food and sports, alongside the spread of (American) English as an international lingua franca (Lieber and Weisberg 2002; Steger 2013). This American primacy is merely a manifestation of the United States' hegemonic power in the cultural sphere, and it is bound to evoke resistance, conflicts and even clashes between cultures. To some advocates, it is the cultural difference and the richness of human culture that should be celebrated (Lieber and Weisberg 2002; Pieterse 1996).

As an activity intrinsically involving cultural exchange, tourism can raise the awareness of cultural differences by increasing cross-cultural communication (Pieterse 1996), while cultivating cultural hybridization that allows for the cohabitation and integration of different cultures. Cultural exploration can be regarded as a dimension of visitors' motives to attend festival events (Crompton and McKay 1997), though culture itself is already a key pull factor.

\subsection{Three perspectives on globalization}

While it is generally agreed that the technics, economics, politics and culture are the main influential forces behind globalization, academics are divided by their perspectives on the developments of globalization. As Held et al. (1999) summarize, those academics are the hyperglobalizers (or hyperglobalists), the sceptics (or traditionalists) and the transformationalists. Table 1 presents the main arguments of each perspective, which are useful for understanding the claims, beliefs and narratives of different academics. 
Table 1 - Key arguments of different perspectives on globalization

\begin{tabular}{|l|l|}
\hline & \\
\hline Hyperglobalizers & $\begin{array}{l}\text { Main arguments } \\
\text { - Globalization is an economic-driven process; } \\
\text { - A homogenized global market exists; } \\
\text { - State power starts to dismantle; } \\
\text { - A global civic society emerges. }\end{array}$ \\
\hline \multirow{5}{*}{ Sceptics } & $\begin{array}{l}\text { - Globalization is an economic-driven process; } \\
\text { - It follows a linear developmental trajectory; } \\
\text { - The world economy is undergoing a process of regionalization; } \\
\text { - State power is still crucial and imposes obstacles to mobility; } \\
\text { - Civilizations are fragmented into several blocs. }\end{array}$ \\
\hline Transformationalists & $\begin{array}{l}\text { - It follows a non-linear developmental trajectory; } \\
\text { - State power is shared at transnational, national and local levels; } \\
\text { - Local culture and global culture coexist. }\end{array}$ \\
\hline
\end{tabular}

Both the hyperglobalizers and the sceptics ponder globalization as an economicdriven process. Globalization is seen as a singular condition of human society (Munar 2007), which in its ideal form is characterized by an integrated global economy. Their difference lies in the beliefs that, for the hyperglobalizers, the increasingly integrated world exists today; whereas in the opinions of the sceptics, the extent of contemporary globalization is wholly exaggerated because the current levels of economic integration have not matched the ideal form of globalization (Held et al. 1999). In terms of politics and culture, the hyperglobalizers are more optimistic about the emergence of a global civil society and argue that the state power starts to dismantle; on the contrary, the sceptics take a more conservative view that people are indeed bounded within a nation state due to obstacles to mobility (Cohen 2012) and civilizations are fragmented into several blocs instead of a homogenized global culture (Held et al. 1999). In the context of tourism, the hyperglobalizers perceive tourists as the consumers that bring the culture of consumerism to developing countries and contribute to the rising of a global society; for the sceptics, the national, cultural identity is emphasized, as tourists are homogenized consumers of one country, and national typification applies to them when they are abroad (Munar 2007).

The transformationalists take a more encompassing view. They argue that globalization intertwines with all key domains of human activities. Globalization is not seen following a linear logic and linear developmental pathway. Moreover, the nation states have to share their monopolistic power with other political structures at both transnational and local levels. Culturally, local and global are no longer understood as mutually exclusive. Tourists are considered not only consumers or 
national representatives of their country, but also global citizens that entail certain rights and duties when they are on the move (Munar 2007). 


\section{Integration of Tourism-Related Sectors}

On the tourism supply side, the worldwide tourism sector is dominated by transnational corporations (TNC) of airlines, hotels, tour operators, and so on. These corporations are characterized by high levels of vertical and horizontal integration (Jafari, Baretje, and Buhalis 2000). To account for how the integration progresses, the line of thinking includes corporate expansion, international division of production and then integration of value chains, throughout which the economic forces are present (see Section 2.2). Meanwhile, the other forces such as technics, politics and culture also play their parts.

In the context of tourism, the key feature of its integration is the recognition of interdependence between members in a supply chain and the generation of strategies that support the efficient integration of various links (Zhang, Song, and Huang 2009). Hjalager (2007) summarizes the four stages of globalization, a framework that is compatible with the "ownership-location-internationalization (OLI)" framework reviewed by Stabler, Papatheodorou, and Sinclair (2010).

The four stages correspond to the process towards a globalized tourism sector. In stage one, companies set out to attract overseas customers to consume tourism products in the companies' home market (or existing destination). The perishable nature of tourism products dictates that tourism consumption is often confined to a specific place. For example, Disneyland theme parks can only be "consumed" in certain cities. Hjalager (2007) notes the marketing efforts of tourism companies to reach out to overseas customers, in the form of tourism board representation or marketing collaboration. On the one hand, placing agents and offices in foreign markets is one of the most commonly used globalization strategies, and has been employed by almost all business sectors. It is believed that the presence in foreign markets helps to bridge cultural and language barriers. Thanks to technological innovations such as social media, destination management organizations (DMOs) and tourism companies can establish their presence in the virtual space, with the potential to reach out to customers regardless of their locations. Social media facilitates instant information dissemination, awareness promotion and interactive communication (Hays, Page, and Buhalis 2013; McCann 2008). On the other hand, joint marketing is observed among companies which supply part(s) of a complex product. This creates the advantages of scale in promotional activities and reduces the complexity facing customers. Notable examples are the major airline alliances Star, SkyTeam and Oneworld (Fletcher and Westlake 2006).

Stage two concerns the integration across borders through investments. While stage one is an initial step to seek expansion through marketing, stage two deals with how companies materialize their presence in an overseas market. As Hjalager (2007) elaborates, this can be achieved via taking ownership of physical facilities (e.g., via mergers and acquisitions), or importing/exporting intangible assets through franchising and licensing. Taking ownership entitles companies to establish overseas subsidiaries, so that they can serve customers directly in the overseas location. Ownership investments also allow companies to gain control over factors of production such as labor, capital and land resources. Moreover, by owning (parts of) a supply chain across different countries, companies may be able to exercise their oligopolistic and oligopsonistic power and achieve dominance in a specialized business field. Lafferty and Van Fossen (2001) note the synergies among hospitality, gambling and entertainment, citing the giant casino-hotels in Nevada, USA as an 
example (e.g., Caesars World, Circus Circus and Mirage Resorts). In the meantime, investments can be made with companies' intangible assets, such as brands, copyrights and trademarks. Franchising and licensing make an efficient use of these intangible assets to facilitate rapid corporate expansion. Embedded with business concepts and know-how, many franchise and licensing arrangements generate the beneficial side-effect of disseminations of technology and knowledge (Hjalager 2007).

As noted at the beginning of this section, transnational integration takes place both vertically and horizontally. The profitability created through vertical integration constitutes the logic of stage three (Hjalager 2007). This process is also termed the international fragmentation, or division of production. It is tightly linked to the business practices of outsourcing. Nowak, Petit, and Sahli (2010) note that the main forces propelling the increased fragmentation in service sectors are the differences in factors' prices (also noted by Hjalager 2007), investment liberalization and reduced communication and transport costs. Theoretically, the underpinnings of vertical integration can be traced to the concept of comparative advantage, which denotes a country's overall ability to carry out particular economic activities more efficiently than other activities and thus predicts a country's specialization of production in the global value chain. In tourism, one of the frameworks that are often cited is the Heckscher-Ohlin (H-O) theorem, which emphasizes the role of a country's endowments of factors of production in determining its comparative advantage (see Stabler, Papatheodorou, and Sinclair 2010; Zhang and Jensen 2007). All in all, stage three is well in line with the logic of market dynamics introduced in Section 2.2.

Stage two and three share many elements found in the "ownership-locationinternationalization (OLI)" framework. It argues that the underlying reason for corporate expansion is to enjoy ownership advantages, which include capital and human resource endowments, intellectual property rights and patents (Stabler, Papatheodorou, and Sinclair 2010). In addition to allowing companies to exercise their oligopolistic and oligopsonistic power, the "O" is also associated with a company's effort to diversify its business risks. The " $\mathrm{L}$ " concerns the access to specific foreign country resources and positive business environments such as highquality and low-cost labor force, adequate infrastructure, tax concessions and government funding. The physical presence in foreign markets assists in overcoming trade barriers and other protectionist impediments, and reducing the cognitive and psychological distance. The "I" allows a company to drastically reduce transaction costs in acquiring inputs and to minimize uncertainty by exercising direct control over its intangible assets, such as logos, images and brand names.

While stages one, two and three embody the process of a growing globalization, the integration does not end within a specific sector. As hypothesized by Hjalager (2007), stage four is a relatively advanced stage, where added value is created via integration with other sectors. This stage is characterized by transcending into new value chains. In the context of tourism, it is argued that the division between tourism on the one hand, and knowledge industries, marketing businesses and media on the other, is blurring (Hjalager 2007).

It is worth noting that the four-stage framework demonstrates a linear view of globalization. As defined by Hjalager (2007), the first three stages belong to the low globalization profile, whereas the fourth is regarded as the high globalization profile. Such distinction may inevitably invite the interpretation that in the end globalization 
will reach an advanced, final and fixed state, which is in line with the hyperglobalists' viewpoint. They understand globalization as a singular condition of human society, a single global market and a "denationalization" of economies through the establishment of transnational networks of production, trade and finance (Held et al. 1999; Munar 2007). The four-stage framework may be subject to criticism from the commentators with a sceptic or transformationalist view. The sceptics argue that globalization is not yet a reality in that the world economy is indeed undergoing regionalization and at best heightened levels of internationalization, whereas the transformationalists see globalization as a long-term historical process without specifying a final, fixed state of globalized world (Held et al. 1999). 


\section{Economic Interdependence of Tourism Demand}

Globalization exists not only in the supply side of tourism, but it also defines the increasingly interconnected tourism demand around the world. Countries are bound by strong economic ties through tourism activities, such that tourism demand exhibits co-movements across countries. Figure 1 shows the co-movements of international tourism receipts across top destinations.

Although the influential forces behind globalization tend to be reasoned in relation to the supply side developments, it is not surprising that the same forces also foster the interdependence of tourism demand across countries. After all, the mass tourism following World War II with the advent of jet airplanes in the early 1960s has led to, and been facilitated by, the increased involvement of transnational corporations in the supply side of tourism system (Jafari, Baretje, and Buhalis 2000). As asserted in Section 2, the surge of technological developments in transportation means has rendered the possibility of frequent and long distance travel at affordable costs. Apart from the reduced transportation costs, the growing affluence and the emergence of new middle classes around the world also contribute to the conspicuous consumption of tourist facilities and services (Azarya 2004; Cohen 2012). Moreover, the innovations in communication technologies, especially the internet, give rise to online travel communities where (the consumption of) travel experience is exchanged and the homogenization of lifestyle is "involuntarily" encouraged. With the expanding and globalizing tourism sector, the Western consumerist ethos spread into remote parts of the non-Western world (Cohen 2012; Smeral 1998). 


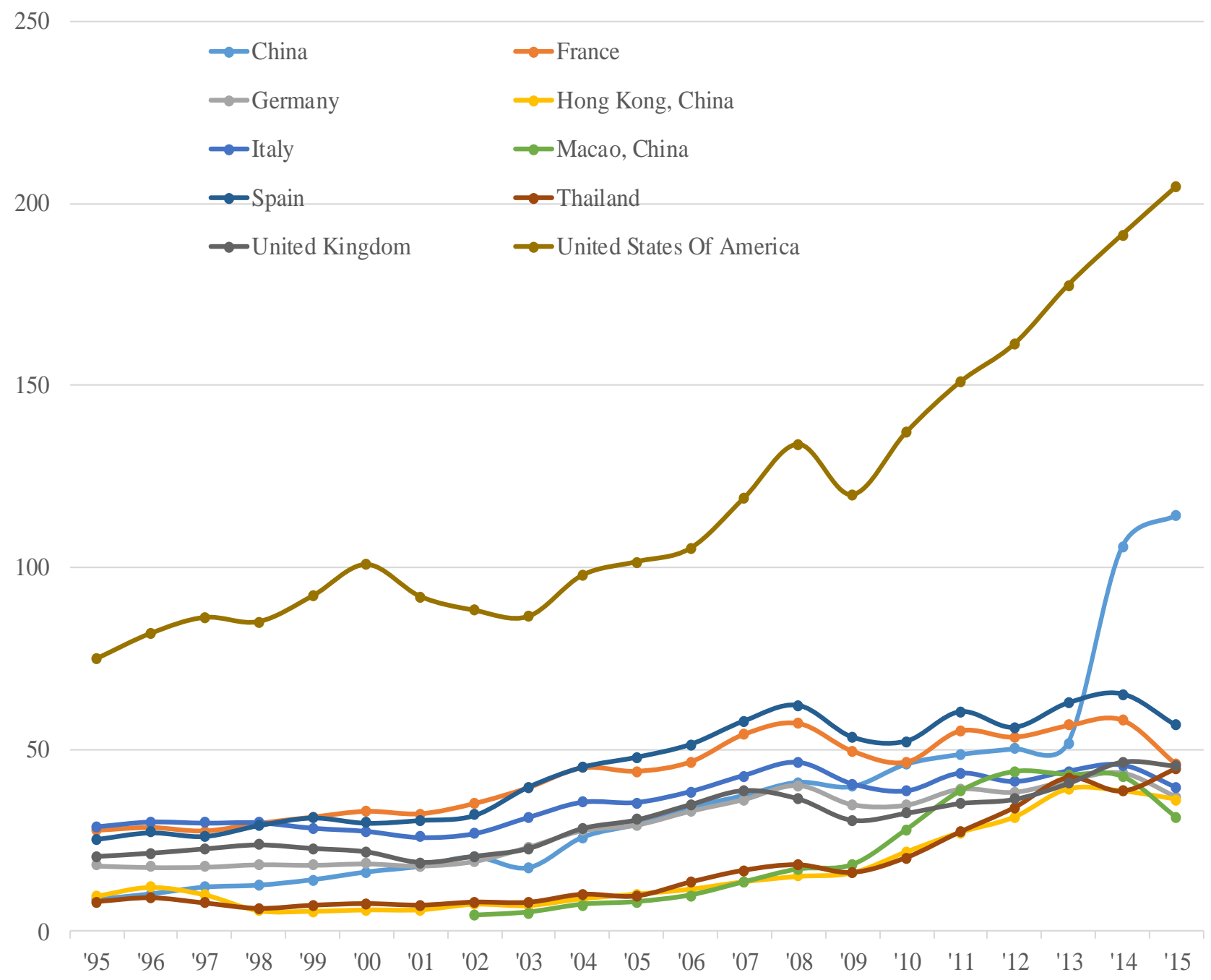

Source: Adapted from UNWTO (2016)

Figure 1 - International Tourism Receipts of Top Destinations (US\$ billion)

\section{The balance between inbound tourism and outbound tourism}

For a specific country, its economic interdependence on the rest of the world can be examined with regard to how much the country depends on and is depended on by other countries. The balance between inbound tourism demand and outbound tourism demand indicates a country's position against the others in an interconnected world. Consequently, the pattern that developed countries are more likely to register trade deficit on their travel account, while developing countries tend to see trade surplus on the same account, pronounces the particular significance of the tourism sector to developing countries (Jafari, Baretje, and Buhalis 2000; Stabler, Papatheodorou, and Sinclair 2010).

\section{Inbound tourism and local economy}

For a destination country, economic impacts of inbound tourism are primarily understood as income and employment generation. This is often elaborated through 
the multiplier effect, which denotes the comparison between economy-wide final benefits for a destination and the initial demand by tourists. In short, the expenditure by inbound tourists brings not only direct income to tourism-related businesses, but also indirect and induced benefits to the wider economy through the backward linkages between sectors and the re-spending of tourism-related incomes (Stabler, Papatheodorou, and Sinclair 2010). Over time, the initial tourism demand exerts knock-on effects on the destination's overall output, stimulates economic growth and ultimately elevates the income level of local people.

Transcending the economic impacts, tourism also has profound social benefits. It is a labor-intensive sector. According to WTTC (2015), the tourism sector creates far more jobs worldwide than other sectors such as automotive manufacturing, chemicals industry and banking industry, while it is only behind the retail and agriculture sectors. Hence, compared with other export sectors, tourism is highly instrumental in lifting people out of poverty and reducing inequality especially for less developed countries.

Detecting the causal relationship between inbound tourism demand and local economic growth is a recurring topic. The Tourism-Led-Growth (TLG) hypothesis, which highlights the role of inbound tourism in earning foreign exchange, spurring investments and diffusing technical knowledge (Schubert, Brida, and Risso 2011), has been tested against empirical evidence (see for example, Balaguer and CantavellaJorda, 2002; Belloumi 2010; Katircioglu 2009; Kim, Chen, and Jang 2006; Narayan et al. 2010; Nowak, Sahli, and Cortes-Jimenez 2007; Seetanah 2011). However, the hypothesis has been supported for certain countries only. An explanation is that inbound tourism may have detrimental effects on local economy. It has been observed that a tourist boom may lead to the de-industrialization of local economy (Copeland 1991; Holzner 2011; Nowak and Sahli 2007). Because a tourist boom tends to raise the demand for and accordingly the prices of non-tradables such as historical and cultural attractions, restaurants and retailing, expanding their production at the expense of the tradable sectors, especially the manufacturing sector (Chao et al. 2006; Stabler, Papatheodorou, and Sinclair 2010). Furthermore, in the cases where supplies of the non-tradables and the tradables are relatively inelastic, the demand caused by a tourist boom would inevitably push up the general consumer prices and impose extra costs on local residents. Therefore, in pursuing a tourism-led growth economy, a country needs to weigh up the benefits and the detrimental effects of tourism.

Given that inbound tourism demand is principally dictated by economic factors in various source countries, a country's tourism sector and even the country's overall economic performance are susceptible to its external economic climate, which is shaped by the synchronization of business cycles across countries (see Section 5), an intrinsic feature of globalization.

\section{Spillovers via outbound tourism}

For a source country, outbound tourism is a channel through which the country's economic fluctuations are spilled over to foreign countries. It follows that the spending of outbound tourists is largely determined by their income level, which is closely linked to the economic situation in their home country. A temporary adverse shock to the source country's gross domestic output (GDP), or unusual turbulences in the foreign exchange market, may lead to a contraction of tourist outflows. As a result, the destination countries will feel the temporary shock accordingly because less 
tourism income will be registered. The welfare-decreasing effect of a temporary demand shock (recession) abroad has been theoretically studied by Schubert and Brida (2009) under a dynamic general equilibrium setting.

The spillovers from a source country can affect a particular destination directly; they can also affect other destination countries in an indirect manner. On the one hand, the effect of the spillovers on a particular destination will be commensurate with the market share of the source country; on the other hand, the spillovers can be transmitted to other countries further afield through the highly integrated supply chain of the tourism sector (see Section 3) and through resident re-spending.

It is worth mentioning that the effect of spillovers on foreign countries should not be overstated. A shock to a small economy may not create catastrophic impacts worldwide, unless it affects other major economies that have more weight in the world. Even though it is difficult to define a "small economy", many countries fit well into this category in the sense that they possess some of the common characteristics of small economies, such as limited diversification, openness, and access to external capital (Commonwealth Secretariat 2000).

\section{Complementary and substitutive relations between destination countries}

While the interdependent nature of tourism demand is mainly underlain by the economic ties across destinations, it is also the product of the complementary and substitutive relations between destination countries.

Destinations are perceived to be complements if a drop in tourism prices in one destination results in an increase in tourism demand for other destinations. One explanation for this complementary relation is that some countries can be visited on a single trip because they are bundled in a holiday package. For example, Singapore, Malaysia and Thailand are often within a single holiday package, and it is very popular with Chinese tourists. Another explanation is that some countries adopt a common visa policy and abolish border control at their common borders, hence enabling a cross-country trip during a single visit. The Schengen Area that comprises 26 European countries is a notable example. In contrast to the complements, the interrelation of some other destinations contains elements of competition because they are perceived as substitutes. For example, the Spanish islands (Balearic, Canary, etc.) and the Greek islands (Crete, Corfu, etc.) are both alluring places for summer holidays, while in the winter Austria, France and Switzerland are all major destinations for skiing. Tourists may well choose a destination after a price hike in the alternative ones. The complementary and substitutive relations between destinations are associated with a wider range of underpinnings such as climate, geographical proximity, cultural similarity, destination attractions/facilities and political reasons (e.g., visa policy).

Empirical studies capture the interrelations between destinations using the concept of cross-price elasticity. Generally, among a set of alternative destinations, the value of cross-price elasticity varies from one source country to another, and the elasticity changes over time (see Li et al. 2006; Song, Witt, and Li 2003; Peng et al. 2015). This reflects that the perception of destination interrelation is rather country-specific and time-varying. Some other studies take a particular look at the substitutive relation (for example, Dwyer, Forsyth, and Dwyer 2010; Li et al. 2013; Mangion, Durbarry, and Sinclair 2005), since the cross-price elasticity signifies how keen the competition 
between destinations is and it is relevant for businesses in a destination to formulate their pricing strategy. 


\section{Business cycles, global crises and tourism}

Interdependence between countries results in co-movements of economic activities on the global scale. As Panić $(2003,8)$ notes, "When international economic interdependence reaches a certain level, what happens in one group of economies may have a major impact on another group - even when the volume of direct trade between the two is small - through the effect on a third group with which both these groups trade heavily." A regional economic crisis may well develop into a global event, as seen in recent years.

\subsection{Business cycle synchronization}

In theory, a business cycle refers to the periodic fluctuations of aggregate economic activities in terms of GDP, employment and so on (Mankiw 2006). It comprises periods of expansions, recessions and revivals in the level of output around the economy's long-term growth trend (Abel, Bernanke, and Croushore 2008; Sørensen and Whitta-Jacobsen 2010). In practice, the duration of business cycles can range from 6 quarters to 43 quarters with an average of slightly below 25 quarters, according to Everts (2006)'s analysis on America's data (see Everts 2006 for more discussions).

In the era of increasing economic integration, the conventional wisdom is that crosscountry interdependence leads to synchronization of business cycles. However, an alternative view suggests that there are also asynchronous output fluctuations because the production of goods is highly specialized and country-specific (Canova and Ciccarelli 2012). An explanation for the different views is that production cycles could be completely idiosyncratic since they are linked to relatively long-term supplyside factors (e.g., capital accumulation, technological catch-up and demographics), while consumption cycles are highly correlated since they are linked more to shorterterm demand-side factors (Canova and Ciccarelli 2012; Derviş 2012).

Many studies have been found under the labels of business cycle synchronization, international transmission mechanism, decoupling and recoupling and international contagion (e.g., Artis, Fidrmuc, and Scharler 2008; Canova and Ciccarelli 2012; Hamori 2000; Sayek and Selover 2002). Based on a sample of 106 countries over the period of 1960-2008, Kose, Otrok, and Prasad (2012) find that there is a substantial convergence of business cycles among industrial economies and among emerging market economies, but there is also a concomitant divergence (or decoupling) of business cycles between these two groups.

To explain the mechanism behind the synchronization of business cycles (i.e., the trigger and the path of transmission), two main hypotheses have been put forth: locomotive hypothesis and common shocks (Bagliano and Morana 2010; Sayek and Selover 2002; Selover 1999). The locomotive hypothesis assumes that idiosyncratic business cycles are transmitted across countries via trade flows, capital movements, labor migration and technological transfer. The shocks that have been examined are usually on income, price and interest rate (Sayek and Selover 2002). The common shocks hypothesis concerns the shocks that affect a majority of countries, such as technological advancement and commodity supply shocks (e.g., oil crises in the 1970s). Regardless of the hypothesis, a shock to any economic variable of a particular country may have far-reaching impacts on other variables of both the local economy and foreign countries. 
In the context of tourism, studies relevant to the business cycles of tourism demand have been very limited, even though the earliest one dates to the late 1970s and is by Schulmeister (1979). The topics of existing studies include that a specific country's tourism demand follows the wider economic fluctuations (e.g., Frechtling 1982; Guizzardi and Mazzocchi 2010) and that tourism demand elasticities evolve across different phases of a business cycle (e.g., Smeral 2012). However, few studies have considered the interdependence between countries. Under the presence of shocks, economic interdependence means that a country's international tourism sector is highly sensitive to idiosyncratic shocks in other countries and global common shocks. As Held et al. $(1999,15)$ comment, “... and the growing extensity, intensity and velocity of global interactions may also be associated with a deepening enmeshment of the local and global such that the impact of distant events is magnified while even the most local developments may come to have enormous global consequences. In this sense, the boundaries between domestic matters and global affairs may be blurred." For example, World Travel and Tourism Council (WTTC 2011) summarizes some unprecedented global events that have disrupted the world tourism sector throughout 2011. These include economic instability in the wake of the financial crisis since 2008, natural disasters such as the nuclear accident in Japan after a devastating tsunami and the earthquake in Christchurch in New Zealand, and socio-political upheaval seen in North Africa and the Middle East. Both tourism consumption and tourism production around the world were severely deterred.

\subsection{Impacts of the recent global economic crisis}

The recent global economic crisis, ignited by the subprime mortgage crisis in the USA in 2008, is an example of the counter-trends to globalization. Moreover, it demonstrates that a country-specific shock can have global implications.

As a non-necessary consumer product and an industry that penetrates many other sectors in an economy, international tourism was hit by the economic slump in an allencompassing manner. The UNWTO data show that international tourism started to decline during the second quarter of 2008, and even plummeted by $8 \%$ in terms of arrivals between January and April 2009 (Papatheodorou, Rosselló, and Xiao 2010; Smeral 2010). The International Air Transport Association (IATA) confirmed the slump by finding an $8 \%$ decline in worldwide passenger traffic between January and May 2009; hotel performance between January and April 2009 registered a similar drop, with revenue per available room falling by double-digit rates (Smeral 2010). The contraction of tourism activities was alleviated from 2010, but still subject to adverse economic climates.

In reviewing the performance of world tourism in 2011, which was believed to be the toughest year since the outbreak of the economic crisis, WTTC (2011) summarizes a combination of factors that contributed to the challenging global macroeconomic environment: uncertainty over the future of eurozone, weakening global businesses and investor confidence, sluggish performance of the United States' economy, slowdown in the main emerging economies and high levels of public debts, borrowing and increasing government austerity. On the finance front, the financial activity and credit growth remained subdued in many economies, restricting the expansion capacity of tourism companies (Papatheodorou, Rosselló, and Xiao 2010). In addition, the recession also led to a downturn in the world labor market. The International Labor Organization (ILO) highlighted that the world unemployment rate, one of 
government's management targets, could reach between $6.5 \%$ and $7.4 \%$ in 2009

(Papatheodorou, Rosselló, and Xiao 2010).

Table 1 - International Tourist Arrivals (million)

\begin{tabular}{|c|c|c|c|c|c|c|c|c|c|c|c|c|}
\hline & \multicolumn{2}{|c|}{1990} & \multicolumn{2}{|c|}{1995} & \multicolumn{2}{|c|}{2000} & \multicolumn{2}{|c|}{2005} & \multicolumn{2}{|c|}{2010} & \multicolumn{2}{|c|}{2015} \\
\hline World & 435 & & 527 & & 674 & & 809 & & 950 & & 1,186 & \\
\hline Advanced economies & 299 & $68.7 \%$ & 339 & $64.3 \%$ & 424 & $62.9 \%$ & 470 & $58.1 \%$ & 516 & $54.3 \%$ & 653 & $55.0 \%$ \\
\hline Emerging economies & 136 & $31.3 \%$ & 188 & $35.7 \%$ & 250 & $37.1 \%$ & 339 & $41.9 \%$ & 434 & $45.7 \%$ & 533 & $45.0 \%$ \\
\hline By UNWTO regions & & & & & & & & & & & & \\
\hline Europe & 261.5 & $60.1 \%$ & 304.5 & $57.8 \%$ & 386.6 & $57.4 \%$ & 453.2 & $56.0 \%$ & 489.4 & $51.5 \%$ & 607.7 & $51.2 \%$ \\
\hline Asia and the Pacific & 55.9 & $12.9 \%$ & 82.1 & $15.6 \%$ & 110.4 & $16.4 \%$ & 154.0 & $19.0 \%$ & 205.5 & $21.6 \%$ & 279.2 & $23.5 \%$ \\
\hline Americas & 92.8 & $21.3 \%$ & 108.9 & $20.7 \%$ & 128.2 & $19.0 \%$ & 133.3 & $16.5 \%$ & 150.2 & $15.8 \%$ & 192.6 & $16.2 \%$ \\
\hline Africa & 14.8 & $3.4 \%$ & 18.7 & $3.5 \%$ & 26.2 & $3.9 \%$ & 34.8 & $4.3 \%$ & 50.4 & $5.3 \%$ & 53.5 & $4.5 \%$ \\
\hline Middle East & 9.6 & $2.2 \%$ & 12.7 & $2.4 \%$ & 22.4 & $3.3 \%$ & 33.7 & $4.2 \%$ & 54.7 & $5.8 \%$ & 53.3 & $4.5 \%$ \\
\hline
\end{tabular}

Source: Adapted from UNWTO (2016)

One emerging trend from the crisis is that developing economies are playing an increasingly important role in the world economy. Structurally, international tourism used to be dominated by developed countries, in that most international tourists originated in and traveled to developed countries, while tourism in developing countries was dominated by tourists from developed countries. Hence, economic policies and economic situations in the developed countries have great impacts on destinations (Jafari, Baretje, and Buhalis 2000). However, it is now formally recognized by the $\mathrm{G} 7$ countries that major developing countries are important pillars of the world's financial system (Papatheodorou, Rosselló, and Xiao 2010). On the one hand, the market share of emerging economies in terms of inbound tourism arrivals increases from $30 \%$ in 1980 to $45 \%$ in 2015, and is expected to reach $57 \%$ by 2030 (UNWTO 2016). This is further evidenced by the contrast of evolution between the market share of Europe and that of Asia Pacific. As Table 2 shows, the share of Europe declined from 60.1\% in 1990 to 51.2\% in 2015, while that of Asia Pacific significantly increased from $12.9 \%$ to $23.5 \%$ during the same period. On the other hand, outbound tourism from developing countries help to restore reciprocity and stability of international trade. Over the last two decades China has shown the fastest growth in terms of expenditure on international tourism, thanks to its rising disposable income, a relaxation of restrictions on foreign travel and an appreciating currency (UNWTO 2015). In 2009, when the world economy was severely hit by the economic crisis, China's tourism expenditure registered a whopping $21 \%$ increase, whereas other top spenders saw near zero or even negative growth (UNWTO 2010). In 2005 China ranked seventh in international tourism expenditure in 2005. Then it had since overtaken Italy, Japan, France, the UK, the USA and Germany to become the world's top spender in 2012 (UNWTO 2013). Another impressive emerging top spender is Russia. It climbed one place in 2013 to become the fourth largest outbound market, following a $25 \%$ increase of tourism expenditure (UNWTO 2014 2015). Such up-rise 
of developing countries is bound to affect not only the pattern of international trade, but also the exchange rate regime. Although it is premature to argue that the Chinese yuan will eventually mount to a global dominance, it is clear that the US dollar is less exclusively relied on for international business transactions, including tourism (Papatheodorou, Rosselló, and Xiao 2010). The euro, a strong contender, is however mired in the debt crisis of its member states. All in all, the dynamics of currency market will certainly change the landscape of world tourism markets on both the demand side and the supply side. 


\section{Concluding Remarks and Opportunities for Future Research}

Developments of globalization have been a spectacular phenomenon over the past few decades. A sector that has immediate linkages with international trade, finance and mobility of people, tourism is a crucial area where globalization is nurtured and strengthened. From the above exploration of the supply side and the demand side of tourism sector, it is obvious that the interdependence between countries has rendered new research directions.

While globalization as a topic has already attracted a rich body of literature, it is less extensively explored within tourism. Generally, the studies of globalization in the context of tourism are conceptual and rely on descriptive facts and discrete cases. Since globalization operates on an ideological dimension, those studies are often filled with a variety of contesting norms, claims, beliefs and narratives. Quantitative methods are seldom used. Hence, quantitative evidence is often lacking.

Future empirical research may seek to provide more quantitative evidence to examine the globalization of tourism sector. This may require econometric models to deal with endogeneity issues among variables and to capture the spatial spillover effects. To this end, vector autoregressive (VAR) types of models such as global VAR (GVAR) and panel VAR (see Canova and Ciccarelli 2013 for a review), spatial-temporal regression types of models (e.g., Marrocu and Paci 2013; Yang and Wong 2012) and a combination of VAR and spatial analysis (see Beenstock and Felsenstein 2007 for an introduction to spatial VAR modeling) are particularly relevant.

With regard to research directions, closely related to the economic interdependence discussed in Sections 4 and 5.1, the first direction can be the synchronization of business cycles of tourism demand. This means measuring the correlations or comovements of tourism demand across countries, for example, using indicators such as an elasticity. From a theoretical point of view, measuring the business cycle synchronization helps to understand the intensity of global interconnectedness. On the practical front, quantifying the scale of co-movements helps tourism businesses gauge the changes of their native market performance in the face of external economic changes.

The second direction concerns the convergence of productivity of tourism or its subsectors across countries. Studies can use cross-country panel data and focus on finding out the reasons for the discrepancies in productivity and the changes of productivity resulting from mergers and acquisitions. As explained in Section 3, the integration of tourism businesses takes a few stages. No matter whether it is vertical or horizontal, cross-country integration facilitates the diffusion of knowledge, technology and management expertise. As a result, over the long run there is a catchup process for less developed countries and an improvement of productivity across the supply chain. At the micro level, productivity can be explored in relation to such factors as seasonality, firm size and inhomogeneity of demand. Although it is not an entirely new concept, productivity convergence has not been rigorously investigated in the context of tourism and its related sectors such as hotels and airlines.

The third direction concerns the impact of shocks or special events on either the demand side or the supply side. An example evidenced in Section 5.2, the recent economic crisis has huge implications on the landscape of the worldwide tourism sector. Future research can attempt to quantify the impacts of other types of events, for example terrorist attacks, which change tourists' risk perception of a destination 
and the security of tourism attractions. From a theoretical point of view, the size of the impact of a distant event manifests the degree of globalization.

The fourth direction can be elicited with regard to policies enhancing destination competitiveness. Measuring the interdependence of tourism demand and that of tourism productivity across countries is an initial step to evaluate the economic performance of a destination against other destinations. For policy makers, a further question is how to maintain and improve their destination's economic performance in the face of external changes. The forces behind the global changes listed in Section 2 are a good starting point for investigation. Policies may be formulated around how to react to and make use of the different forces.

The fifth direction may look into the counter-globalization movements since the economic crisis of 2008 (e.g., increased protectionist pressure and anti-immigrant sentiment seen in some parts of the world, as discussed in Section 2), reacting to the uneven development of globalization. Such research requires transcending econometric methods and seeking theoretical perspectives from disciplines such as politics and geography. The transdisciplinary nature of globalization research echoes the multi-faceted nature of globalization. It would be interesting to find out whether or not the movements have led the world towards further regionalization, rendering tourism businesses, tourists and local residents regional-focused.

The themes and specific topics discussed in all the previous sections and the suggested future research directions are summarized in the table below.

Table 3 - Summary of the main topics reviewed and suggested

\section{Theme: Influential forces}

- The key forces behind the process of globalization

- The three perspectives on the developments of globalization

Future research directions

- How a destination enhances its competitiveness by reacting to the influential forces behind globalization

- How the counter-globalization movements in recent years impact on the tourism sector

\section{Theme: Supply side}

- The different stages and forms of integration among tourism businesses

Future research direction

- To what extent the productivity of tourism businesses converges across countries as a result of integration

Theme: Demand side

- The interdependence of tourism demand across different destination countries

- The causal relationship between tourism demand and economic growth

Future research direction

- To what extent tourism demand co-moves across countries

\section{Theme: Global events}

- The mechanism behind the synchronization of business cycle

- The impact of the global economic crisis since 2008 on tourism

Future research direction

- To what extent a regional event impacts on the tourism sector globally 


\section{References}

Abel, A. B., B. Bernanke, and D. D. Croushore. 2008. Macroeconomics 6th ed. Boston; London: Pearson/Addison Wesley.

Artis, M. J., J. Fidrmuc, and J. Scharler. 2008. "The transmission of business cycles Implications for EMU enlargement." Economics of Transition 16 (3): 559-582.

Azarya, V. 2004. "Globalization and international tourism in developing countries: Marginality as a commercial commodity." Current Sociology 52 (6): 949-967.

Bagliano, F. C., and C. Morana. 2010. "Business cycle comovement in the G-7: common shocks or common transmission mechanisms?" Applied economics 42 (18): 2327-2345.

Balaguer, J., and M. Cantavella-Jorda. 2002. "Tourism as a long-run economic growth factor: the Spanish case." Applied economics 34 (7): 877-884.

Beenstock, Michael, and Daniel Felsenstein. 2007. "Spatial vector autoregressions." Spatial Economic Analysis 2, no. 2: 167-196.

Belloumi, M. 2010. "The relationship between tourism receipts, real effective exchange rate and economic growth in Tunisia." International Journal of Tourism Research 12 (5): 550-560.

Ben-David, Dan, and Michael B. Loewy. 1998. "Free trade, growth, and convergence." Journal of economic growth 3, no. 2: 143-170.

Bussière, Matthieu, Emilia Pérez - Barreiro, Roland Straub, and Daria Taglioni. 2011. "Protectionist responses to the crisis: Global trends and implications." The World Economy 34, no. 5: 826-852.

Canova, F., and M. Ciccarelli. 2012. "ClubMed? Cyclical fluctuations in the Mediterranean basin." Journal of International Economics 88 (1): 162-175.

Canova, F., and M. Ciccarelli. 2013. "Panel Vector Autoregressive Models: A Survey." ECB Working Paper Series No 1507. Frankfurt, Germany: European Central Bank.

Chao, C., B. R. Hazari, J. Laffargue, P. M. Sgro, and E. S. H. Yu. 2006. "Tourism, Dutch Disease and Welfare in An Open Dynamic Economy." The Japanese Economic Review 57 (4): 501-515.

Cohen, E. 2012. "Globalization, global crises and tourism." Tourism recreation research 37 (2): 103-111.

Commonwealth Secretariat. 2000. "Small states: meeting challenges in the global economy." Report of the Commonwealth Secretariat/World Bank Joint Task Force on Small States. http://www.cpahq.org/cpahq/cpadocs/meetingchallengeinglobaleconomyl.pdf (accessed December 15, 2014)

Copeland, B. R. 1991. "Tourism, welfare and de-industrialization in a small open economy." Economica 58 (232): 515-529.

Cornelissen, S. 2005. The global tourism system: governance, development and lessons from South Africa. Aldershot: Ashgate Publishing Ltd. 
Crompton, J. L., and S. L. McKay. 1997. "Motives of visitors attending festival events." Annals of Tourism Research 24 (2): 425-439.

Derviş, K. 2012. "Convergence, Interdependence, and Divergence." Finance \& Development 49 (3): 10-14.

Dicken, P. 2011. Global shift: Mapping the changing contours of the world economy. New York: The Guilford Press.

Dwyer, L., D. Edwards, N. Mistilis, C. Roman, and N. Scott. 2009. "Destination and enterprise management for a tourism future." Tourism management 30 (1): 63-74.

Dwyer, L., P. Forsyth, and W. Dwyer. 2010. Tourism economics and policy. Bristol: Channel View Publications.

Ederer, Stefan, and Peter Reschenhofer. 2014. A global value chain analysis of macroeconomic imbalances in Europe. No. 67. WWWforEurope. http://www.foreurope.eu/fileadmin/documents/pdf/Workingpapers/WWWforEurope_ WPS_no067_MS221.pdf (accessed January 17, 2017)

Everts, Martin. 2006. "Duration of business cycles." https://papers.ssrn.com/sol3/papers.cfm?abstract_id=905804. (accessed January 15, 2017)

Fayed, H., and J. Fletcher. 2002. "Report: Globalisation of economic activity: issues for tourism." Tourism Economics 8 (2): 207-230.

Fletcher, J., and J. Westlake. 2006. "Globalisation". In International handbook on the economics of tourism, edited by L. Dwyer and P. Forsyth, 464-480. Cheltenham: Edward Elgar Publishing.

Frechtling, D. C. 1982. "Tourism trends and the business cycle: tourism in recession." Tourism Management 3 (4): 285-290.

Guizzardi, A., and M. Mazzocchi. 2010. "Tourism demand for Italy and the business cycle." Tourism Management 31 (3): 367-377.

Guttal, S. 2007. "Globalisation." Development in Practice 17 (4/5): 523-531.

Hamori, S. 2000. "The transmission mechanism of business cycles among Germany, Japan, the UK and the USA." Applied Economics 32 (4): 405-410.

Hays, S., S. J. Page, and D. Buhalis. 2013. "Social media as a destination marketing tool: its use by national tourism organisations." Current issues in Tourism 16 (3): 211-239.

Held, D., A. McGrew, D. Goldblatt, and J. Perraton. 1999. Global transformations: politics, economics and culture. Stanford, Calif.: Stanford University Press.

Hjalager, A. M. 2007. "Stages in the economic globalization of tourism." Annals of Tourism Research 34 (2): 437-457.

Holzner, M. 2011. "Tourism and economic development: The beach disease?" Tourism Management 32: 922-933.

Jafari, J., R. Baretje, and D. Buhalis, eds. 2000. Encyclopedia of tourism. London: Routledge. 
Katircioglu, S. T. 2009. "Revisiting the tourism-led-growth hypothesis for Turkey using the bounds test and Johansen approach for cointegration." Tourism Management 30 (1): 17-20.

Kim, H. J., M. Chen, and S. Jang. 2006. "Tourism expansion and economic development: The case of Taiwan." Tourism Management 27: 925-933.

Kose, M. A., C. Otrok, and E. Prasad. 2012. "GLOBAL BUSINESS CYCLES: CONVERGENCE OR DECOUPLING?" International Economic Review 53 (2): 511-538.

Lafferty, G., and A. Van Fossen. 2001. "Integrating the tourism industry: problems and strategies." Tourism Management 22 (1): 11-19.

Lee, Seoki. 2008. "Internationalization of US multinational hotel companies: expansion to Asia versus Europe." International Journal of Hospitality Management 27, no. 4: 657-664.

Li, G., H. Song, Z. Cao, and D. C. Wu. 2013. "How competitive is Hong Kong against its competitors? An econometric study." Tourism Management 36: 247256.

Li, G., K. K. Wong, H. Song, and S. F. Witt. 2006. "Tourism demand forecasting: A time varying parameter error correction model." Journal of Travel Research 45 (2): 175-185.

Lieber, R. J., and R. E. Weisberg. 2002. "Globalization, culture, and identities in crisis." International Journal of Politics, Culture, and Society 16 (2): 273-296.

Mahon, Rianne. 2010. "After neo-liberalism? The OECD, the World Bank and the child." Global Social Policy 10, no. 2: 172-192.

Mangion, M. L., R. Durbarry, and M. T. Sinclair. 2005. "Tourism competitiveness: price and quality Tourism competitiveness: price and quality." Tourism economics 11 (1): 45-68.

Mankiw, N. G. 2006. Macroeconomics $6^{\text {th }} e d$. New York: Worth Publishers.

Marrocu, E, and R. Paci. 2013. "Different tourists to different destinations. Evidence from spatial interaction models." Tourism Management 39: 71-83.

McCann, P. 2008. "Globalization and economic geography: the world is curved, not flat." Cambridge Journal of Regions, Economy and Society 1 (3): 351-370.

McGrew, A. 2011. "The logics of economic globalisation" In Global political economy, edited by J. Ravenhill, 275-311. New York: Oxford University Press.

Munar, A. M. 2007. "Rethinking globalisation theory in tourism." Tourism Culture \& Communication 7 (2): 99-115.

Mussa, Michael. 2000. "Factors driving global economic integration." Global economic integration: Opportunities and challenges: 9-55.

Narayan, P. K., S. Narayan, A. Prasad, and B. C. Prasad. 2010. "Tourism and economic growth: A panel data analysis for pacific island countries." Tourism Economics 16 (1): 169-183. 
Neumayer, E. 2006. "Unequal access to foreign spaces: how states use visa restrictions to regulate mobility in a globalized world." Transactions of the Institute of British Geographers 31 (1): 72-84.

Neumayer, E. 2011. "On the detrimental impact of visa restrictions on bilateral trade and foreign direct investment." Applied geography 31 (3): 901-907.

Nowak, J. J., S. Petit, and M. Sahli. 2010. "Tourism and globalization: the international division of tourism production." Journal of Travel Research 49 (2): 228-245.

Nowak, J., and M. Sahli. 2007. "Coastal tourism and 'Dutch disease' in a small island economy." Tourism Economics: 13 (1): 49-65.

Nowak, J. J., M. Sahli, and I. Cortes-Jimenez. 2007. "Tourism, capital good imports and economic growth: theory and evidence for Spain." Tourism Economics 13 (4): $515-536$.

Panić, M. 2003. Globalisation and national economic welfare. Basingstoke: Palgrave Macmillan.

Papatheodorou, A., J. Rosselló, and H. Xiao. 2010. "Global Economic Crisis and Tourism: Consequences and Perspectives." Journal of Travel Research 49 (1): 3945.

Peng, B., H. Song, G. Crouch, and S. Witt. 2015. "A meta-analysis of international tourism demand elasticities" Journal of Travel Research 54 (5): 611-633.

Pieterse, J. N. 1996. "Globalisation and culture: Three paradigms." Economic and Political Weekly: 1389-1393.

Redding, Stephen. 1999. "Dynamic comparative advantage and the welfare effects of trade." Oxford economic papers 51, no. 1: 15-39.

Sayek, S., and D. D. Selover. 2002. "International interdependence and business cycle transmission between Turkey and the European Union." Southern Economic Journal 69 (2): 206-238.

Scholte, Jan Aart. 2005. "The sources of neoliberal globalization." Vol. 10. UNRISD. http://unrisd.org/UNRISD/website/document.nsf/ab82a6805797760f80256b4f005da1ab /9e1c54ceeb19a314c12570b4004d0881/\$FILE/scholte.pdf (accessed January 13, 2017)

Schubert, S. F., and J. G. Brida. 2009. "Macroeconomic effects of changes in tourism demand: a simple dynamic model." Tourism Economics 15 (3): 591-613.

Schubert, S. F., J. G. Brida, and W. A. Risso. 2011. "The impacts of international tourism demand on economic growth of small economies dependent on tourism." Tourism Management 32 (2): 377-385.

Schulmeister, S. 1979. Tourism and the business cycle: econometric models for the purpose of analysis and forecasting of short-term changes in the demand for tourism. Vienna: Austrian Institute for Economic Research.

Seetanah, B. 2011. "Assessing the dynamic economic impact of tourism for island economies." Annals of Tourism Research 38 (1): 291-308. 
Selover, D. D. 1999. "International interdependence and business cycle transmission in ASEAN." Journal of the Japanese and International Economies 13 (3): 230253.

Simmons, Beth A., and Zachary Elkins. 2004. "The globalization of liberalization: Policy diffusion in the international political economy." American political science review: 171-189.

Smeral, E. 1998. "The impact of globalization on small and medium enterprises: new challenges for tourism policies in European countries." Tourism management 19 (4): 371-380.

Smeral, E. 2010. "Impacts of the World Recession and Economic Crisis on Tourism: Forecasts and Potential Risks." Journal of Travel Research 49 (1): 31-38.

Smeral, E. 2012. "International tourism demand and the business cycle." Annals of Tourism Research 39 (1): 379-400.

Song, H., W. C. Gartner, and A. D. Tasci. 2012. "Visa restrictions and their adverse economic and marketing implications-Evidence from China." Tourism Management 33 (2): 397-412.

Song, H., S. F. Witt, and G. Li. 2003. "Modelling and forecasting the demand for Thai tourism." Tourism Economics 9 (4): 363-387.

Sørensen, P. B., and H. J. Whitta-Jacobsen. 2010. Introducing advanced macroeconomics: growth and business cycles. New York: McGraw-Hill higher education.

Stabler, M., A. Papatheodorou, and M. T. Sinclair. (2010). The economics of tourism 2nd ed. New York: Routledge; London: Taylor \& Francis.

Steger, M. B. 2005. "Globalism: The New Market Ideology". In The Logos Reader: Rational Radicalism and the Future of Politics, edited by S. Bronner and M. J. Thompson, 341-352. Lexington, KY: University Press of Kentucky.

Steger, M. B. 2013. Globalization: A very short introduction. Oxford: Oxford University Press.

Tribe, J. 2011. Economics of recreation, leisure and tourism $4^{\text {th }}$ ed. Oxford: Elsevier.

United Nations. 2016. “International Migration Report 2015: Highlights (ST/ESA/SER.A/375)". http://www.un.org/en/development/desa/population/migration/publications/migrationr eport/docs/MigrationReport2015_Highlights.pdf (accessed May 9, 2017)

United Nations World Tourism Organization (UNWTO). 2010. "Tourism Highlights." http://www.e-unwto.org/content/t60255/fulltext.pdf (accessed September 2, 2012)

United Nations World Tourism Organization (UNWTO). 2013. "UNWTO Tourism Highlights, 2013 Edition." http://mkt.unwto.org/publication/unwto-tourismhighlights-2013-edition (accessed April 1, 2014)

United Nations World Tourism Organization (UNWTO). 2014. "UNWTO Tourism Highlights, 2014 Edition." http://mkt.unwto.org/publication/unwto-tourismhighlights-2014-edition (accessed June 15, 2015) 
United Nations World Tourism Organization (UNWTO). 2015. "UNWTO Tourism Highlights, 2015 Edition." http://www.eunwto.org/doi/pdf/10.18111/9789284416899 (accessed September 9, 2015)

United Nations World Tourism Organization (UNWTO). 2016. "UNWTO Tourism Highlights, 2016 Edition." http://www.eunwto.org/doi/pdf/10.18111/9789284418145 (accessed January 16, 2017)

Williams, Mariama. 2002. "The Political Economy of Tourism Liberalization, Gender and the GATS"

http://citeseerx.ist.psu.edu/viewdoc/download?doi=10.1.1.466.1847\&rep=rep1\&ty pe=pdf (accessed May 9, 2017)

Winters, L. Alan, Terrie L. Walmsley, Zhen Kun Wang, and Roman Grynberg. 2003. "Liberalising temporary movement of natural persons: an agenda for the development round." The World Economy 26, no. 8: 1137-1161.

World Travel and Tourism Council (WTTC). 2011. "The Review 2011." http://www.wttc.org/site_media/uploads/downloads/WTTC_Review_2011.pdf (accessed August 3, 2013)

World Travel and Tourism Council (WTTC). 2015. "Benchmarking Travel \& Tourism: How does Travel \& Tourism compare to other sectors." https://www.wttc.org/-/media/files/reports/benchmark-reports/regional-results2015/global-benchmarking-report-2015.pdf (accessed February 21, 2017)

Yang, Y., and K. K. F. Wong. 2012. "A spatial econometric approach to model spillover effects in tourism flows." Journal of Travel Research 51 (6): 768-778.

Zhang, Jie, and Camilla Jensen. 2007. "Comparative advantage: explaining tourism flows." Annals of tourism research 34, no. 1: 223-243.

Zhang, X., H. Song, and G. Q. Huang. 2009. "Tourism supply chain management: A new research agenda." Tourism management: 30 (3): 345-358. 